\title{
PENGARUH HARGA, E-PROMOSI DAN KEPERCAYAAN, TERHADAP KEPUTUSAN PEMBELIAN SECARA ONLINE DI APLIKASI LAZADA (Studi Kasus Pada Mahasiswa Universitas Satya Negara Indonesia Kampus A)
}

\author{
Fitriati Oktavani, Lucy Nancy *
}

\begin{abstract}
*)Dosen Tetap Program S1 Jurusan Manajemen Fakultas EkonomiUniversitas Satya Negara Indonesia Email:fitriatioktavanii33@gmail.com; Lucynancysim@gmail.com
\end{abstract}

\begin{abstract}
This research aims to determine the impact of price, e-promotion, and trust on purchasing decisions online in the Lazada app. The method used in this research is the quantitative method and assessment of the results based on respondents 'answers using a Likert scale. The population in this study is of Satya Negara Indonesia University student A the samples in this study amounted to 86. The data analysis methods used in the study are test linear regression test Multiple, F-Test, T-Test, and coefficient of determinant. The results showed that simultaneously (test $F$ ) showed that there was a significant influence between the price variables (X1), the e-promotion (X2), and the trust (X3) against the purchase decision (Y). Partial (T-Test) the price is influential as significant to the purchase decision, and the epromotion is influential as significant to Purchase decision. whereas the trust variable does not influential as significant to the purchase decision.
\end{abstract}

\section{Keyword: Price, E-promotion, Trust and Purchasing Decisions}

\section{PENDAHULUAN}

Perkembangan teknologi dan informasi di dunia khususnya internet mengalami perkembangan yang sangat pesat. Internet menjadi salah satu media yang tidak hanya digunakan untuk berkomunikasi, melainkan dapat digunakan sebagai media berbelanja. Hal ini menjadikan internet sebagai kebutuhan pokok sebagian besar orang selain kebutuhan pangan, sandang, papan. Gaya hidup masyarakat saat ini ikut mengalami perubahan karena adanya pengaruh dari perkembangan teknologi tersebut, salah satu yang paling menyolok dari perkembangan tersebut adalah gadget dan kecenderungan beraktivitas di dunia maya seperti berbelanja secara online.

Pola perilaku masyarakat tersebut pula yang dapat menggeser gaya konsumsi masyarakat yang tadinya toko konvensional (offline) menjadi toko daring/ online.

Tabel 1

Pengunjung Lazada tahun 2018

\begin{tabular}{|c|c|c|c|c|}
\hline No. & $\begin{array}{c}\text { Data Per } \\
\text { Kuartal }\end{array}$ & $\begin{array}{c}\text { Visitor Per } \\
\text { Bulan }\end{array}$ & $\begin{array}{c}\text { App Store } \\
\text { Rank }\end{array}$ & Play Store Rank \\
\hline 1. & Jan - Mar 2018 & $117,5 \mathrm{jt}$ & $\# 4$ & $\# 3$ \\
\hline 2. & Apr - Juni 2018 & $49,9 \mathrm{jt}$ & $\# 3$ & $\# 2$ \\
\hline 3. & Juli - Sept 2018 & $36,4 \mathrm{jt}$ & $\# 4$ & $\# 2$ \\
\hline 4. & Okt - Des 2018 & $58,2 \mathrm{jt}$ & $\# 3$ & $\# 2$ \\
\hline
\end{tabular}

Tabel 1. menunjukan data pengunjung Lazada pada tahun 2018. Dari data tersebut dapat dinyatakan bahwa pada bulan April-Juni 2018 (kuartal 2) dan Juli-September 2018 (kuartal 3) mengalami penurunan dalam jumlah kunjungan ke website Lazada dan kembali meningkat pada 
bulan Oktober-Desember 2018 (kuartal 4). Dengan adanya penurunan jumlah pengunjung akan mempengaruhi tingkat keputusan pembelian, karena semakin turunnya jumlah pengunjung maka semakin berkurangnya tingkat pembelian pada aplikasi Lazada. Selain itu pada peringkat App Store Lazada mengalami ketidakstabilan tiap kuartalnya, di sisi lain pada peringkat Play Store Lazada mengalami peningkatan dari kuartal 2 hingga 4. Adanya kenaikan dan penurunan dari data yang ada dapat disebabkan oleh beberapa faktor yang mempengaruhinya antara lain Harga yang ditawarkan, E-Promosi yang dilakukan perusahaan, dan Kepercayaan menggunakan aplikasi tersebut.

Berdasarkan latar belakang diatas, peneliti tertarik memilih Judul "PENGARUH HARGA,E-PROMOSI DAN KEPERCAYAAN TERHADAP KEPUTUSAN PEMBELIAN ONLINE DI APLIKASI LAZADA (Studi Kasus Pada Mahasiswa Universitas Satya Negara Indonesia Kampus A)".

\section{TINJAUAN PUSTAKA}

\section{Keputusan Pembelian}

Menurut Kotler dan Keller (2016:198), Keputusan Pembelian merupakan evaluasi, konsumen membentuk preferensi diantara merek-merek didalam rangkaian pilihan dan mungkin juga berbentuk niat untuk membeli merek yang paling disukai.Perilaku Konsumen akan menentukan proses pengambilan keputusan dalam pembelian mereka, proses tersebut merupakan sebuah pendekatan penyesuaian masalah yng terdiri dari lima tahap yang dilakukan konsumen.

\section{Harga}

Menurut Kotler dan Keller (2016) adalah Harga adalah jumlah uang yang harus disiapkan oleh pelanggan yang ingin mendapatkan barang atau jasa.

\section{E-Promosi}

Menurut Kotler dan Amstrong 2012 dalam Lancarya Prastowo (2016) "Promosi Online atau E-promotion adalah sisi pemasaran dari e-commerce, yang terdiri dari kerja suatu perusahaan untuk mengkomunikasikan sesuatu, mempromosikan, dan menjual barang dan jasa dari internet".

\section{Kepercayaan}

Menurut Kotler dan Keller (2016) Kepercayaan adalah kesediaan perusahaan untuk bergantung pada mitra bisnis. Kepercayaan tergantung pada beberapa faktor antar pribadi dan antar organisasi seperti kompetensi, integritas, kejujuran dan kebaikan hati.

\section{Penelitian Terdahulu}

Sukawati (2017) penelitian berjudul "Pengaruh Kepercayaan, Harga dan Kualitas Produk terhadap Keputusan Pembelian melalui Internet dikota Makasar" menyatakan bahwa hasil penelitian variabel harga berpengaruh signifikan terhadap keputusan pembelian.

Feryanto Fure, Joyce dan Rita (2015) penelitian berjudul "Pengaruh Brand Image, Kualitas Produk, Harga terhadap Keputusan Pembelian konsumen di J.CO Manado" menyatakan bahwa hasil penelitian variabel Harga berpengaruh tidak signifikan terhadap Keputusan Pembelian.

Achmad Jamaludin, Zainul Arifin, Kadarismasn Hidayat (2015) penelitian berjudul "Pengaruh Promosi Online dan Persepsi Harga terhadap Keputusan Pembelian Aryka shop di Malang" 
menyatakan bahwa hasil penelitian variabel E-promosi berpengaruh signifikan terhadap Keputusan Pembelian.

Carla Mediana Irawati Putri (2018) penelitian berjudul "Pengaruh Promosi Online dan Kualitas Pelayanan terhdap Keputusan Pembelian konsumen" menyatakan bahwa hasil penelitian variabel E-promosi tidak berpengaruh terhadap Keputusan Pembelian Konsumen.

Fredianaika Istanti (2017) penelitian berjudul "Pengaruh Harga, Kepercayaan, Kemudahan berbelanja dan E-promosi terhadap Keputusan Pembelian belanja Online di kota Surabaya" menyatakan bahwa hasil penelitian variabel Kepercayaan berpengaruh positif terhadap Keputusan Pembelian.

Yuli NurPratiwi, Suprihatmi Sri Wardiningsih, Sumaryanto (2019) penelitian berjudul "Pengaruh Kepercayaan, Kemudahan dan Harga terhadap Keputusan Pembelian melalui situs Online Store Lazada" menyatakan bahwa hasil penelitian variabel Kepercayaan berpengaruh tidak signifikan terhadap Keputusan Pembelian.

\section{Kerangka Pemikiran}

H1

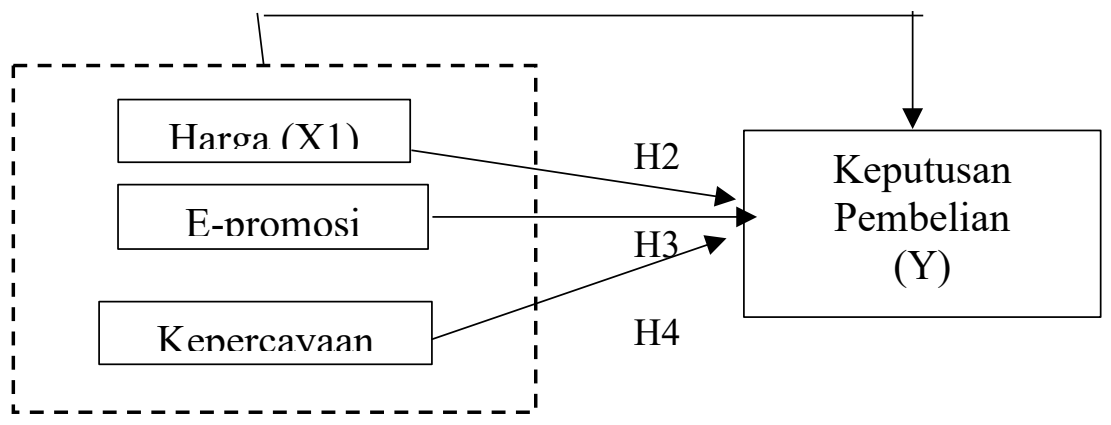

\section{Hipotesis Penelitian}

$\mathrm{H}_{1}$ : Harga, E-promosi, dan Kepercayaan berpengaruh terhadap Keputusan Pembelian online di aplikasi Lazada.

$\mathrm{H}_{2}$ : Harga berpengaruh terhadap Keputusan Pembelian online di aplikasi Lazada.

$\mathrm{H}_{3}$ : $\quad$ E-promosi berpengaruh terhadap Keputusan Pembelian online di aplikasi Lazada.

$\mathrm{H}_{4}$ : Kepercayaan berpengaruh terhadap Keputusan Pembelian online di aplikasi Lazada.

\section{METODE PENELITIAN}

\section{Waktu dan Tempat Penelitian}

Penelitian ini dilakukan di Universitas Satya Negara Indonesia kampus A. Penelitian dilakukan mulai dari bulan Agustus 2019 s/d January 2020.

\section{Desain Penelitian}

Jenis penelitian ini adalah penelitian Kausal (Causal Research) yaitu penelitian untuk mengetahui pengaruh satu atau lebih variabel bebas (independent variable) terhadap variabel terikat (dependent variable) 


\section{Metode Pengumpulan Data}

teknik pengumpulan data yang dipergunakan dalam penelitian ini adalah sebagai berikut:

a. Studi Kepustakaan

dengan membaca dan mempelajari buku-buku dan literatur yang berhubungan dengan masalah yang akan diteliti, guna memperoleh data teoritis yang relevan dengan pokok persoalan yang di bahas

b. Penelitian Lapangan

Penelitian lapangan dilakukan dengan mengadakan penelitian langsung pada objek atau perusahaan yang akan diteliti untuk mengumpulkan data yang diperlukan tersebut melaui wawancara dan kuisuner

\section{Populasi dan Sampel}

Populasi ini dilakukan pada seluruh Mahasiswa Universitas Satya Negara Indonesia Kampus A yang menggunakan aplikasi Lazada tahun akademik 2019/2020. Dalam penelitian ini, tehnik sampling yang digunakan oleh peneliti adalah tehnik Non Probalility Sampling.Metode pengambilan sampel dalam penelitian adalah dengan menggunakan Accidental Sampling.Penetapan sampel dengan menggunakan rumus Roscoe dengan penetapan sampel yang digunakan yaitu:

$$
\mathrm{n}=10 \times \mathrm{K}
$$

$\mathrm{n}=(10) \times 4=40$

Keterangan:

$\mathrm{n}=$ Responden

$\mathrm{k}=$ variable penelitian yang digunakan

$10=$ jumlah observer menurut Roscoe

Mengingat berbagai pertimbangan seperti waktu, tenaga, fasilitas dan kondisi maka sampel yang di gunakan sebanyak 120.setelah melalui uji Normalitas data, data yang dapat diolah hanya sebanyak 86 responden, terdapat beberapa data yang ekstrem yang harus di keluarkan.

\section{ANALISIS HASIL DAN PEMBAHASAN}

\section{Uji Deskriptif}

Analisis deskriptif digunakan untuk menggambarkan tentang statistik data seperti min, max, mean, sum, standard deviasi, variance, range, dan lain-lain, untuk mengukur distribusi data dengan skewness dan kurtosis.

Tabel 2. Descriptive Statistics

\begin{tabular}{|l|l|l|l|l|l|l|}
\hline & N & Minimum & Maximum & Sum & Mean & $\begin{array}{l}\text { Std. } \\
\text { Deviation }\end{array}$ \\
\hline Keputusan Pembelian & 86 & 62 & 106 & 7528 & 87.53 & 9.867 \\
Harga & 86 & 50 & 75 & 5425 & 63.08 & 5.263 \\
E-promosi & 86 & 61 & 94 & 6690 & 77.79 & 6.760 \\
Kepercayaan & 86 & 71 & 114 & 8012 & 93.16 & 8.743 \\
Valid N (listwise) & 86 & & & & & \\
\hline
\end{tabular}

Sumber: Output SPSS Ver.23, 2020

\section{Uji Validitas}


Uji Validitas bertujuan untuk mengetahui seberapa cermat suatu item dalam mengukur apa yang ingin diukur (kuisioner)(Priyatno, 2017:63).Hasil yang didapat penulis merupan seluruh pernyataan valid sesuai dengan hasil SPSS penulis yang mana $r$ hitung $>r$ tabel .

\section{Uji Reliabilitas}

Menurut Priyatno (2017:79) Uji reliabilitas digunakan untuk mengetahui keajegan atau konsistensi alat ukur yang biasanya menggunakan kuesioner. Hasil yang didapat penulis merupan seluruh pernyataan Reliabel sesuai dengan hasil SPSS dengan nilai Cronbach Alpha> 0,6 yang berarti reliabel.

\section{Uji Asumsi Dasar}

\section{Uji Normalitas Dasar}

Uji normalitas dasar bertujuan untuk mengetahui apakah data yang dihasilkan dari regresi terdistribusi secara normal atau tidak. Model regresi yang baik adalah yang memiliki nilai yang terdistribusi secara normal. Pengujian menggunakan statistik Uji Kolmogorov-Smirnov, data dikatakan berdistribusi normal jika nilai signifikansi $>0,05$

Tabel 3. Hasil Uji Tests of Normality

Tests of Normality

\begin{tabular}{|l|r|r|r|}
\hline \multirow{2}{*}{} & \multicolumn{3}{|c|}{ Kolmogorov-Smirnov } \\
\cline { 2 - 4 } & Statistic & \multicolumn{1}{c|}{ df } & \multicolumn{1}{c|}{ Sig. } \\
\hline Keputusan Pembelian & .091 & 86 & .077 \\
Harga & .093 & 86 & .066 \\
E-promosi & .094 & 86 & .059 \\
Kepercayaan & .083 & 86 & $.200^{*}$ \\
\hline
\end{tabular}

Sumber: Output SPSS Ver.23, 2020

Dapat disimpulkan Harga (X1), E-Promosi (X2), Kepercayaan (X3) dan Keputusan Pembelian (Y) mempunyai nilai nilai Kolmorogof - smirnov $>0,05$ maka menunjukan data distribusi normal.

\section{Uji Asumsi Klasik}

\section{Uji Normalitas Residual}

Uji Normalitas residual dilakukan untuk menguji nilai residual yang dihasilkan dari regresi terdistribusi secara normal. Model regresi yang baik adalah yang memiliki nilai yang terdistribusi secra normal. Pengujian menggunakan statistik Uji Metode Grafik P-Plot, data dikatakan berdistribusi normal, jika titik-titik menyebar sekitar garis dan mengikuti garis diagonal. 


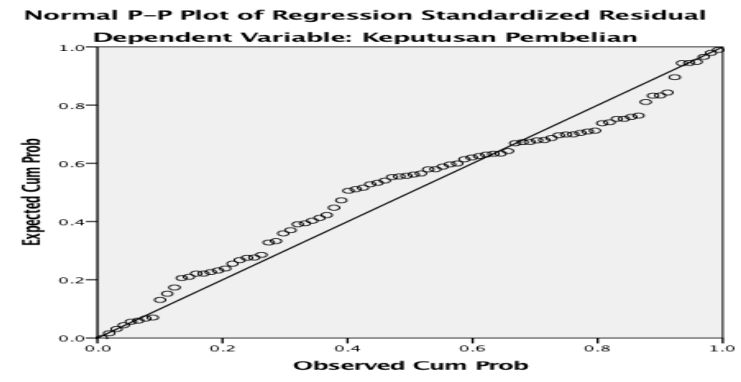

Sumber: Output SPSS Ver.23, 2020

Gambar diatas menunjukan grafik normal probability plot yang menunjukan bahwa data menyebar disekitar garis diagonal dan mengikuti arah garis diagonal, maka model regresi pada gambar 1, telah memenuhi asumsi uji normalitas.

\section{Uji Multikolinieritas}

Menurut Priyatno (2017:120), Multikolinieritas artinya antara variabel independen yang terdapat dalam model regresi memiliki hubungan linear yang sempurna atau mendekati sempurna (koefisien korelasinya tinggi atau bahkan 1).

Tabel 3. Hasil Uji Multikolinieritas

\section{Coefficients $^{\mathrm{a}}$}

tabel 4

\begin{tabular}{|c|c|c|c|c|c|c|c|c|}
\hline \multirow[b]{2}{*}{ Model } & & \multicolumn{2}{|c|}{$\begin{array}{l}\text { Unstandardized } \\
\text { Coefficients }\end{array}$} & $\begin{array}{l}\text { Standardized } \\
\text { Coefficients }\end{array}$ & \multirow[t]{2}{*}{$\mathrm{T}$} & \multirow[t]{2}{*}{ Sig. } & \multicolumn{2}{|c|}{ Collinearity Statistics } \\
\hline & & $\mathrm{B}$ & Std. Error & Beta & & & Tolerance & VIF \\
\hline \multirow[t]{4}{*}{1} & (Constant) & 2.713 & 10.805 & & .251 & .802 & & \\
\hline & Harga & .556 & .204 & 297 & 2.724 & .008 & .583 & 1.716 \\
\hline & E-promosi & .480 & .206 & .329 & 2.332 & .022 & .348 & 2.873 \\
\hline & Kepercayaan & .133 & .160 & .118 & .836 & .406 & .345 & 2.897 \\
\hline
\end{tabular}

Sumber: Output SPSS Ver.23, 2020

hasil uji Multikolinieritas pada penelitian ini tidak terjadi gejala Multikolinieritas karena semua variabel bebas (independent) memiliki nilai tolerance $>0,1$ dan semua $\mathrm{VIF}<10$

\section{Uji Heteroskedastisitas}

Menurut Priyatno (2017:126) heteroskedastisitas adalah varian residual yang tidak sama pada semua pengamatan di dalam model regresi. Regresi yang baik seharusnya tidak terjadi heteroskedastisitas.

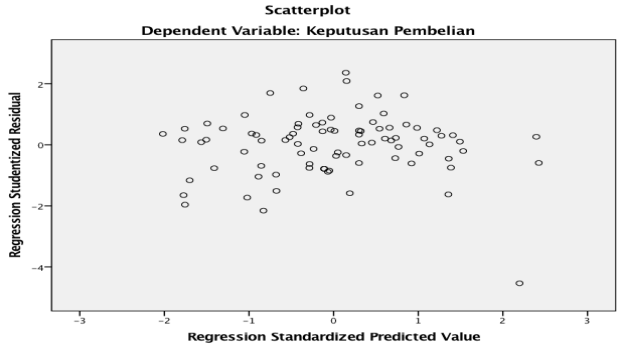

Sumber: Output SPSS Ver.23, 2020

menggunakan grafik scatterplot menunjukan titik menyebar secara acak dibawah serta diatas angka 0 pada sumbu $\mathrm{Y}$, dan tidak mempunyai pola yang teratur.

\section{Uji Autokorelasi}


Menurut Priyatno (2017:123) uji autokorelasi antara anggota observasi yang disusun menurut waktu dan tempat. Model regresi yang baik seharusnya tidak terjadi autokorelasi.Metode pengujian menggunakan uji Durbin-Watson (DW test).

Hasil Uji Autokorelasi

Model Summary

tabel 5

\begin{tabular}{|l|c|r|r|r|r|}
\hline Model & R & R Square & $\begin{array}{c}\text { Adjusted R } \\
\text { Square }\end{array}$ & $\begin{array}{c}\text { Std. Error of } \\
\text { the Estimate }\end{array}$ & Durbin-Watson \\
\hline 1 & $.658^{\mathrm{a}}$ & .433 & .413 & 7.562 & 1.835 \\
\hline
\end{tabular}

Sumber: Output SPSS Ver.23, 2020

Menunjukan bahwa nilai Durbin Watson sebesar 1,835. Dengan jumlah sampel 86, dan jumlah variabel independent 3 (k-3), dengan level signifikan 5\% didapatkan nilai $1,7221<1,835<2,2779$ Ho diterima yang berarti tidak terjadi autokorelasi pada model regresi.

\section{Uji Hipotesis}

\section{Uji F}

Uji $\mathrm{F}$ digunakan untuk menguji ada atau tidaknya pengaruh variabel - variabel independen terhadap variabel dependen secara simultan (bersama - sama), dengan kriteria pengujian sebagai berikut:

a. Jika Fhitung $>$ Ftabel maka Ho ditolak dan Ha diterima.

b. Jika Fhitung $<$ Ftabel maka Ho diterima dan Ha ditolak

Hasil Uji F

\section{ANOVA $^{\mathrm{a}}$}

tabel 6

\begin{tabular}{|cc|c|c|c|c|c|}
\hline Model & & Sum of Squares & df & Mean Square & F & Sig. \\
\hline 1 & Regression & 3585.794 & 3 & 1195.265 & 20.900 & $.000^{\mathrm{b}}$ \\
\cline { 2 - 6 } & Residual & 4689.601 & 82 & 57.190 & & \\
& Total & 8275.395 & 85 & & & \\
\hline
\end{tabular}

Sumber data dioleh penulis melalui SPSS 23 (2020)

hasil uji $\mathrm{f}$ dengan nilai sebesar 20,900 $>2,716$ (f hitung $>\mathrm{f}$ tabel dan nilai signifikasi sebesar 0,000 < 0,05 maka Ho ditolak. Yang artinya Variabel independent (Harga, E-promosi, Kepercayaan) secara simultan berpengaruh positif dan signifikan terhadap variabel dependent (keputusan pembelian).

\section{Uji t (uji parsial)}

Uji statistik $\mathrm{t}$ atau uji parsial digunakan untuk mengetahui apakah model regresi variabel Kepercayaan, Kemudahan, dan Kualitas Informasi secara parsial (sendiri-sendiri) berpengaruh signifikan terhadap variabel dependen yaitu keputusan pembelian jika kolom sig $<$ dari 0,05 dan $\mathrm{t}$ hitung $>\mathrm{t}$ tabel maka $\mathrm{H} 0$ ditolak dan Ha diterima.

\section{Coefficients $^{\mathrm{a}}$}

tabel 7

\begin{tabular}{|c|c|c|c|c|c|c|c|}
\hline \multirow[b]{2}{*}{ Model } & \multicolumn{2}{|c|}{$\begin{array}{l}\text { Unstandardized } \\
\text { Coefficients }\end{array}$} & \multirow{2}{*}{\begin{tabular}{|c|}
$\begin{array}{l}\text { Standardized } \\
\text { Coefficients }\end{array}$ \\
Beta \\
\end{tabular}} & \multirow[b]{2}{*}{$\mathrm{t}$} & \multirow[b]{2}{*}{ Sig. } & \multicolumn{2}{|c|}{$\begin{array}{c}\text { Collinearity } \\
\text { Statistics }\end{array}$} \\
\hline & B & $\begin{array}{l}\text { Std. } \\
\text { Error }\end{array}$ & & & & Tolerance & VIF \\
\hline \multirow{2}{*}{$\begin{array}{l}\text { 1. (Constant) } \\
\text { Harga }\end{array}$} & 2.713 & 10.805 & & .251 & .802 & & \\
\hline & .556 & .204 & .297 & 2.724 & .008 & .583 & 1.716 \\
\hline
\end{tabular}




\begin{tabular}{|l|r|r|r|r|r|r|r|}
\hline E-promosi & .480 & .206 & .329 & 2.332 & .022 & .348 & 2.873 \\
\cline { 2 - 8 } Kepercayaan & .133 & .160 & .118 & .836 & .406 & .345 & 2.897 \\
\hline
\end{tabular}

Sumber data dioleh penulis melalui SPSS 23 (2020)

a. Variabel Harga $(X 1)$ nilai t hitung $>t$ tabel $(2,724>1,989)$ dan nilai signifikansi $(0,008<$ 0,05) maka Ho ditolak, yang artinya Harga berpengaruh signifikan terhadap Keputusan Pembelian.

b. Variabel E-promosi (X2) nilai t hitung $>\mathrm{t}$ tabel $(2,332>1,989)$ dan nilai signifikansi $(0,022$ $<0,05)$ maka Ho ditolak, yang artinya E-promosi berpengaruh signifikan terhadap Keputusan Pembelian.

c. Variabel Kepercayaan (X3) nilai t hitung $<$ t tabel $(0,836<1,989)$ dan nilai signifikansi $(0,406<0,05)$ maka Ho diterima, yang artinya Kepercayaan tidak berpengaruh signifikan terhadap Keputusan Pembelian.

\section{Regresi Linear Berganda}

Menurut Priyatno (2017:169) Analisis linier berganda digunakan untuk mengetahui pengaruh atau hubungan secara linier antara dua atau lebih variabel independen dengan satu variabel dependen.

Hasil Uji Regresi Linear Berganda

Coefficients $^{\mathrm{a}}$

Tabel 8

\begin{tabular}{|c|c|c|c|c|c|c|c|}
\hline \multirow[b]{2}{*}{ Model } & \multicolumn{2}{|c|}{$\begin{array}{l}\text { Unstandardized } \\
\text { Coefficients }\end{array}$} & \multirow{2}{*}{$\begin{array}{c}\text { Standardized } \\
\text { Coefficients } \\
\text { Beta }\end{array}$} & & \multirow[b]{2}{*}{ Sig. } & \multicolumn{2}{|c|}{$\begin{array}{c}\text { Collinearity } \\
\text { Statistics }\end{array}$} \\
\hline & B & $\begin{array}{l}\text { Std. } \\
\text { Error }\end{array}$ & & & & $\begin{array}{c}\text { Tolera } \\
\text { nce }\end{array}$ & VIF \\
\hline \multirow{4}{*}{$\begin{array}{l}\text { 1. (Constant) } \\
\text { Harga } \\
\text { E-promosi } \\
\text { Kepercayaan }\end{array}$} & 2.713 & 10.805 & & .251 & .802 & & \\
\hline & .556 & .204 & .297 & 2.724 & .008 & .583 & 1.716 \\
\hline & .480 & .206 & .329 & 2.332 & .022 & .348 & 2.873 \\
\hline & .133 & .160 & .118 & .836 & .406 & .345 & 2.897 \\
\hline
\end{tabular}

Sumber data dioleh penulis melalui SPSS 23 (2020)

$\mathrm{Y}=2,713+0,556 \mathrm{X}_{1}+0,480 \mathrm{X}_{2}+0,133 \mathrm{X}_{3}$

a. Nilai Konstanta adalah 2,713 yang artinya jika Harga, E-promosi, Kepercayaan terhadap Keputusan Pembelian nilainya 0, maka Keputusan Pembelian akan bernilai sebesar 2,713.

b. Koefisien Regresi Harga (X1) bersifat positif sebesar 0,556 yang artinya jika variabel Harga meningkat 1 satuan, maka akan meningkatkan Keputusan Pembelian sebesar 0,556 dengan asumsi variabel lain tetap.

c. Koefisien Regresi E-promosi (X2) bersifat positif sebesar 0,480 yang artinya jika variabel Epromosi meningkat 1 satuan, maka akan meningkatkan Keputusan Pembelian sebesar 0,480 dengan asumsi variabel lain tetap.

d. Koefisien Regresi Kepercayaan (X3) bersifat positif sebesar 0,133 yang artinya jika variabel Kepercayaan meningkat 1 satuan, maka akan meningkatkan Keputusan Pembelian sebesar 0,133 dengan asumsi variabel lain tetap.

\section{Uji Korelasi}

Analisis korelasi adalah hubungan antara dua variabel. Dalam perhitungan korelasi akan didapat koefisien korelasi yang menunjukan keeratan hubungan antar dua variabel tersebut. 
a. Nilai koefisien korelasi berkisar antara 0 sampai 1 atau 0 sampai -1, nilai semakin mendekati 1 atau -1, maka hubungan semakin erat.

b. Jika nilai koefisien korelasi mendekati 0 maka hubungan semakin lemah. Hasil Uji Korelasi

Correlations

Tabel 9

\begin{tabular}{|l|l|l|l|l|l|}
\hline \multicolumn{2}{|c|}{} & $\begin{array}{l}\text { Keputusan } \\
\text { Pembelian }\end{array}$ & Harga & E-promosi & Kepercayaan \\
\hline Keputusan & Pearson Correlation & 1 & $.569^{* *}$ & $.603^{* *}$ & $.561^{* *}$ \\
Pembelian & Sig. (2-tailed) & & .000 & .000 & .000 \\
& $\mathrm{~N}$ & 86 & 86 & 86 & 86 \\
\hline Harga & Pearson Correlation & $.569^{* *}$ & 1 & $.609^{* *}$ & $.614^{* *}$ \\
& Sig. (2-tailed) & .000 & & .000 & .000 \\
& $\mathrm{~N}$ & 86 & 86 & 86 & 86 \\
\hline E-promosi & Pearson Correlation & $.603^{* *}$ & $.609^{* *}$ & 1 & $.792^{* *}$ \\
& Sig. (2-tailed) & .000 & .000 & & .000 \\
& $\mathrm{~N}$ & 86 & 86 & 86 & 86 \\
\hline Kepercayaa & Pearson Correlation & $.561^{* *}$ & $.614^{* *}$ & $.792^{* *}$ & 1 \\
$\mathrm{n}$ & Sig. (2-tailed) & .000 & .000 & .000 & \\
& $\mathrm{~N}$ & 86 & 86 & 86 & 86 \\
\hline
\end{tabular}

Sumber: Output SPSS Ver.23, 2020

a. Koefisien korelasi antara Harga (X1) dengan Keputusan Pembelian (Y) sebesar 0,569 mendekati 0 dengan signifikansi $0,000<0,05$ menunjukan Harga memiliki korelasi yang cukup sedang terhadap Keputusan Pembelian.

b. Koefisien korelasi antara E-promosi (X2) dengan Keputusan Pembelian (Y) sebesar 0,603 mendekati 0 dengan signifikansi $0,000<0,05$ menunjukan E-promosi memiliki korelasi yang cukup sedang terhadap Keputusan Pembelian.

c. Koefisien korelasi antara Kepercayaan (X2) dengan Keputusan Pembelian (Y) sebesar 0,561 mendekati 0 dengan signifikansi $0,000<0,05$ menunjukan Kepercayaan memiliki korelasi yang cukup sedang terhadap Keputusan Pembelian.

\section{Uji Koefisien Determinasi}

Koefisien determinasi pada intinya mengukur seberapa jauh kemampuan model dalam menerangkan variasi variabel dependen. Nilai koefisien determinasi antara 0 dan 1 . Nilai Hasil Uji Koefisien Determinasi

Model Summary

\begin{tabular}{|l|r|r|r|r|r|}
\hline & & Tabel 10 \\
Model & $\mathrm{R}$ & Square & $\begin{array}{c}\text { Adjusted } \\
\text { R Square }\end{array}$ & $\begin{array}{c}\text { Std. Error } \\
\text { of the } \\
\text { Estimate }\end{array}$ & $\begin{array}{c}\text { Durbin- } \\
\text { Watson }\end{array}$ \\
\hline 1 & $.658^{\mathrm{a}}$ & .433 & .413 & 7.562 & 1.835 \\
\hline
\end{tabular}

Sumber: Output SPSS Ver.23, 2020

Adjusted R Square sebesar 0,413 (41,3\%) artinya menunjukan bahwa presentase sumbangan pengaruh variabel independen (Harga, E-promosi dan Kepercayaan) terhadap variabel dependen (Keputusan Pembelian) adalah sebesar 41,3\% sedangkan sisanya sebesar 58,7\% dipengaruhi oleh variabel lain (kualitas produk, citra merek, kualitas pelayanan dan lain-lain) yang tidak termasuk dalam penelitian ini.

\section{Kesimpulan}

Berdasarkan hasil penelitian ini bertujuan untuk menguji Pengaruh dari Variabel Harga, EPromosi, Kepercayaan terhadap Keputusan Pembelian. 
1. Variabel Harga (X1), E-promosi (X2) dan Kepercayaan (X3) secara simultan berpengaruh signifikan terhadap Keputusan Pembelian (Y) di Lazada. Pengaruhnya sebesar 41\% sedangkan sisanya sebesar 59\% dipengaruhi oleh variabel lain (kualitas produk, citra merek, kualitas pelayanan dan lain-lain) yang tidak termasuk dalam penelitian ini.

2. Variabel Harga (X1) secara parsial berpengaruh signifikan terhadap Keputusan Pembelian (Y) di Lazada.

3. Variabel E-promosi (X2) secara parsial berpengaruh signifikan tehadap Keputusan Pembelian (Y) diLazada.

4. Variabel Kepercayaan (X3) secara parsial tidak berpengaruh dan tidak signifikan terhadap Keputusan Pembelian (Y) di Lazada.

\section{Saran}

1. Harga, E-promosi dan Kepercayaan terhadap Keputusan Pembelian perlu ditingkatkan kembali karna melihat hasil dari penelitian ini, sebaiknya Lazada lebih meningkatkan terkait kepercayaan konsumen terhadap Lazada. Dan faktor lain yang dapat mempengaruhi Keputusan Pembelian.

2. Harga sebagai salah satu variabel yang berpengaruh signifikan terhadap Keputusan Pembelian. Namun banyak mahasiswa menyatakan kurang setuju dan tidak setuju akan pernyataan dari dimensi daftar harga dengan indikator, harga di Lazada lebih murah dibanding dengan Online Shop lainnya. Oleh karena itu Lazada disarankan perlu melakukan penyesuaian harga yang sebanding dengan kualitasnya dan tidak terlalu mahal. Karena jika harga yang ditawarkan terlalu mahal, maka akan menurunkan minat konsumen untuk membeli. Lazada juga dapat menambahkan beberpa program diskon lainnya seperti gratis ongkir pada konsumen tampa harus membeli dengan kuantitas yang banyak. Program gratis ongkir sebaik nya dilakukan dengan minimal pembelanjaan yang tidak terlalu tinggi.

3. E-promosi juga menjadi salah satu variabel yang berpengaruh signifikan terhadap Keputusan Pembelian. Dalam rangka meningkatkan Keputusan Pembelian, Lazada di sarankan untuk selalu mempromosikan dirinya sehingga Lazada dapat melampaui Online Shop lain. Dengan cara selalu aktif

melakukan promosi di internet dengan cara selalu mempertahankan hubungan personal yang baik dengan konsumen seperti, interaksi yang aktif dimedia sosial. Dengan demikian Lazada dapat menjadi situs yang lebih familiar dari situs Online Shop lain.

4. Kepercayaan menjadi satu-satunya variabel yang tidak berpengaruh signifikan terhadap Keputusan Pembelian. Semakin tinggi tingkat kepercayaan konsumen maka akan semakin tinggi juga tingkat Keputusan Pembelian yang dilakukan oleh konsumen. Maka Lazada disarankan untuk lebih meningkatkan pelayanan-pelayanan yang akan meningkatkan rasa percaya di diri konsumen sehingga dapat melakukan pembelian di Lazada tampa rasa ragu. Seperti meningkatkan pelayanan yang lebih efektif dalam hal penangan keluhan, cepat tanggap merespon kebutuhan konsumen, keamanan yang tinggi dan informasi yang sesuai pada deskripsi. Dengan demikian konsumen akan merasa percaya terhadap apa yang diberikan oleh Lazada.

\section{DAFTAR PUSTAKA}

\section{Sumber Buku:}

Alma, Buchari, 2013. Manajemen Pemasaran dan Pemasaran Jasa. Bandung: Alfabeta Assauri, Sojan, 2015. Manajemen Pemasaran, Jakrta: Rajawali

Fandy Tjiptono, Ph.D, 2015. Strategi Pemasaran, Edisi 4. Yogyakarta: Penerbit Andy

Kotler dan Keller, 2009. Manajemen Pemasaran, Edisi 13, Jilid 1. Jakarta: Erlangga

Kotler dan Keller, 2009. Manajemen Pemasaran, Edisi 13, Jilid 2. Jakarta: Erlangga

Priyatno, Duwi, 2017. Panduan praktis olah data menggunakan SPSS. Yoyakarta: Penerbit Andi 
Sugiyono. 2017. Metode Penelitian Kuantitatif, Kualitatif Dan R\&D. Bandung: Alfabeta.

Sumber Jurnal:

Achmad Jamaludin, Zainul Arifin, Kadarismasn Hidayat. 2015. Pengaruh Promosi Online dan Persepsi Harga Terhadap Keputusan Pembelian.

Carla Mediana Irawati Putri. 2018. Pengaruh Promosi Online dan Kualitas Pembelian Terhadap Keputusan Pembelian Konsumen.

Ferdyanto Fure, Joyce Lapian, Rita Taroreh. 2015. Pengaruh Brand Image, Kualitas Produk dan Harga Terhadap Keputusan Pembelian Konsumen Di J.co Manado

Fredianaika Istanti, 2017. Pengaruh Harga, Kepercayaan, Kemudahan Berbelanja dan Epromosi Terhadap Keputusan Pembelian Belanja Online di Kota Surabaya

Irna Fitri. 2016. Analisis Promosi Penjualan Online, Harga, Kepercayaan dan Kemudahan Terhadap Keputusan Pembelian Ceker Brontak.

Maria Carolina, Helen Wijawa. 2015. Analisa Pengaruh Kepercayaan, Kemudahan, Kualitas Informasi, dan Tampilan Produk Terhadap Keputusan Pembelian Melalui Pemasaran Di Media Sosial

Maya,Puspa,S.2015. Pengaruh Kepercayaan, Kemudahan, Dan Kualitas Informasi Terhadap Keputusan Pembelian Secara Online Di Situs Lazada.Co.Id Pada Mahasiswa/I Fakultas Ekonomi Dan Bisnis Usu.

Sukawati 2018. Pengaruh Kepercayaan, Harga, dan Kualitas Produk Terhadap Keputusan Pembelian melalui Internet di Kota Makassar

Yuli Nur Pratiwi, Suprihatmi Sri Wardiningsih, Sumaryanto. 2019. Pengaruh Kepercayaan, Kemudahan dan Harga Terhadap Keputusan Pembelian melalui situs Online Store.

Sumber Website:

Dani Wijaya . (2017).,Tutupnya beberapa gerai konvensional atau toko tradisioonal karena pembeli beralih ke toko "online", Www.Kompasiana.Com/Daniwijaya/5a012fb0c226f97388003462/,

Iprice insight .(2019)., Daftar 50 website \&aplikasi e-commerce di indonesia 2018., https://iprice.co.id/insights/mapofecommerce/

Logopedia. (2015)., Lazada Logopedia Fandom Powerd., https://logos.fandom.com/wiki/Special:Search?search=lazada\&fulltext=Search\&ns6=1 